\begin{tabular}{ll}
\hline \hline MINING AND METALLURGY INSTITUTE BOR & ISSN: 2334-8836 \\
& UDK: 622 \\
\hline \hline
\end{tabular}

Vesna M. Marjanović* Aleksandra T. Ivanović, Vesna Cvetković Stamenković

\title{
SOOT PARTICIPATION IN TOTAL AIR POLLUTION IN THE MUNICIPALITY OF BOR WITH STATISTICAL DATA PROCESSING ${ }^{* *}$
}

\begin{abstract}
For effective air quality management, one of the main conditions is the identification of pollution sources, determining their share in the overall pollution as well as implementation the measures for control and reducing the pollution. The aim of this paper is that, based on collected data, to make a conclusion on how soot affects the level of pollution in the municipality of Bor. The results presented in this paper were obtained on the basis of processed daily and average annual values of soot concentrations for these years. Analysis of samples was carried our on refractometer at 24 hour continuously, seven days a month at a particular measurement point. For statistical data processing, the statistical software SPSS (Statistical Package for the Social Sciences) version 17.0 was used. Based on the results obtained using the software, there is the conclusion that there is little correlation between the metrological parameters and soot concentration in the municipality of Bor, and that there is no increased concentration at the measuring points despite pyrometallurgical treatment of copper concentrate in RTB Bor. The great importance to the increased soot concentration has the use of fossil fuels for heating households, as it is not the case in Bor, because more than $90 \%$ of households are heated by district heating system.
\end{abstract}

Keywords: soot, pollution, Bor municipality, statistical software SPSS

\section{INTRODUCTION}

The Municipality of Bor is located in East Serbia; it covers an area of $856 \mathrm{~km}^{2}$ and there around 50,000 citizens in it, according to the census of 2011 [1,2]. Bor is located at altitude of $378 \mathrm{~m}$, and belongs to the continental climate area. The average annual precipitation is $688 \mathrm{~mm}$, the snow cover remains for 60 days, and the average annual temperature is $10.2^{\circ} \mathrm{C}$. The area of Bor is located in the area of high-frequency winds, but the winds are of moderate intensity. The dominant winds in the study area are NE $(9.9 \%), \mathrm{W}(8.2 \%)$ and NW (7.7\%), and the direction of $\mathrm{E}(7.6 \%)$, the wind from the south direction of lower frequency (4.4\%). The basic meteorological parameters are given in Table 1 [3 - 9]. The standard deviation is shown to see how natural samples on average deviate from arithmetic mean of the sample.

\footnotetext{
* Mining and Metallurgy Institute Bor

** This work is the result of the Project TR 33038 "Improving Technology of Exploitation and Processing of Copper Ore with Monitoring the Living and Working Environment in the RTB Bor Group", funded by the Ministry of Education, Science and Technological Development of the Republic of Serbia
} 
Table 1 Meteorological observations for the period 2005-2010 from the meteorological station at the Mining and Metallurgy Institute in Bor

\begin{tabular}{|c|c|c|c|c|c|c|}
\hline \multirow{2}{*}{ Meteorological parameters } & \multicolumn{6}{|c|}{ Year } \\
\hline & 2005 & 2006 & 2007 & 2008 & 2009 & 2010 \\
\hline \multicolumn{7}{|l|}{ Temperature $\left({ }^{\circ} \mathrm{C}\right)$} \\
\hline Minimum & -2.7 & -3.6 & -0.9 & -1.9 & 0.9 & -3.0 \\
\hline Maximum & 22.0 & 21.6 & 24.7 & 23.2 & 21.9 & 22.9 \\
\hline Average value & 9.9 & 10.1 & 11.7 & 11.4 & 11.3 & 10.5 \\
\hline SD & 8.5 & 8.3 & 8.3 & 8.1 & 7.9 & 8.45 \\
\hline \multicolumn{7}{|l|}{ Air humidity (\%) } \\
\hline Minimum & 64 & 60 & 43 & 54 & 52 & 65 \\
\hline Maximum & 84 & 81 & 86 & 84 & 86 & 83 \\
\hline Average value & 75.3 & 70.5 & 68 & 69 & 67 & 76 \\
\hline SD & 6.27 & 7.06 & 12.93 & 9.76 & 10.95 & 7.41 \\
\hline \multicolumn{7}{|l|}{ Atmospheric pressure (mbar) } \\
\hline Minimum & 965.7 & 965.8 & 967.4 & 949.5 & 966.6 & 964.1 \\
\hline Maximum & 978.5 & 981.5 & 976.7 & 980.4 & 975.1 & 972.5 \\
\hline Average value & 971.9 & 972.7 & 971.6 & 971.1 & 971.0 & 969.4 \\
\hline SD & 3.3 & 4.6 & 2.7 & 7.6 & 3.8 & 3.46 \\
\hline \multicolumn{7}{|l|}{ Wind speed $(\mathrm{m} / \mathrm{s})$} \\
\hline Minimum & 0.1 & 0.3 & 0.4 & 0.3 & 0.2 & 0.3 \\
\hline Maximum & 0.8 & 0.7 & 0.8 & 1.0 & 1.0 & 2.2 \\
\hline Average value & 0.45 & 0.45 & 0.55 & 0.6 & 0.5 & 0.8 \\
\hline SD & 0.25 & 0.13 & 0.17 & 0.19 & 0.28 & 0.80 \\
\hline \multicolumn{7}{|l|}{ Maximum wind gust $(\mathrm{m} / \mathrm{s})$} \\
\hline Minimum & 4.4 & 8.2 & 11.3 & 10.3 & 7.8 & 5.3 \\
\hline Maximum & 17 & 17.0 & 18.4 & 19.6 & 19.4 & 16.8 \\
\hline Average value & 12.6 & 13.6 & 14.0 & 16.5 & 13.9 & 12.2 \\
\hline SD & 3.8 & 3.1 & 2.4 & 2.8 & 3.5 & 4.73 \\
\hline
\end{tabular}

$S D$ - standard deviation

\section{SOURCES OF POLLUTION}

The primary sources of pollution in Bor are mining and metallurgy. Pollution comes from the process of mining and processing of copper ore, and a source of pollution is also the overburden from the open pit and flotation tailing dumps.

The secondary source of pollution is the soot that is produced by combustion of fossil fuels. A quantity of soot in the air originates from traffic and the emission is present throughout the year, while the second quan- tity of soot is typical for the winter (heating) season and it originates from the central town heating plant, which use coal as fuel.

\section{MEASURING POINTS}

The layout of measuring points depends on the type of settlement, meteorological and topographical factors of the area, the position of industrial facilities, layout of main roads, as well as the nature and amount 
of gas emissions. Monitoring of air quality in the area of the municipality of Bor is performed at the following measuring points:

1. Town Park: measuring point is 800 $\mathrm{m}$ far in the direction WSW of the Mining and Smelter Basin Bor as the dominant source of pollution. It is located in the urban area of the town (Local Community Old Center). Measuring point is situated in the old part of the town where there are the major business, trading and administrative town facilities.

2. Mining and Metallurgy Institute Bor: measuring point is $1,900 \mathrm{~m}$ far in the direction SSW in the urban area of the town. Measuring point is located in the most densely inhabited part of the town. In the vicinity of the measuring point, there are several schools, major roads and the sports and recreation center.

3. Jugopetrol: measuring point is 2,500 $\mathrm{m}$ far in the direction SSE from the source of pollution. In the area around this measuring point, the smallest numbers of inhabitants live. It is located in the area of suburb, which is the industrial zone. The area is significant for being the gust of winds with the highest frequency.

4. Brezonik: measuring point is $2.000 \mathrm{~m}$ far in the direction NNW in the area of suburb. [10]

\section{AIR POLLUTION}

The concept of air pollution is the specific content of harmful substances in the air. The amount and types of these substances depends on the damage that can cause the human and animal health, as well as plants and materials. Pollutants can be in solid, liquid or gaseous state. Solid particle is the term used to describe particles that are suspended in the air.

Suspended particles are pollutants that differ in size, mass, surface, chemical composition, mechanism of formation and origin. Their concentration in the air is a function of the emission source, reactions in the atmosphere and meteorological conditions.
Suspended particles are mixture of very fine solid particles and liquid drops, which consist of a number of components, including acids (nitrates and sulfates), organic matter, metals, non-metals, soot, dust and soil particles. [11]

According to the size, the solid particles can be divided into: coarse particles (2.5-10 $\mu \mathrm{m}$ ) arising from mechanical resuspension of dust, erosion and soil treatment or for-ming from the industrial processes such as production of cement, concrete, ceramics and mining. Characteristic elements which are concentrated in this fraction are $\mathrm{Al}, \mathrm{Si}, \mathrm{Ca}, \mathrm{Fe}$ and $\mathrm{Na}$; fine particles $(<2.5 \mu \mathrm{m})$ originating from anthropogenic activities such as: combustion, various industrial processes and traffic. Particles of diameter $<1 \mu \mathrm{m}$ are formed by condensation of metals or organic matters from the combustion process and ultrafine particles (from 0.01 to $0.1 \mu \mathrm{m}$ ) in the atmosphere are in the form of an aerosol. Ultrafine particles are usually derived from the combustion of diesel fuel, gasoline and other organic fuels; they are composed of particles of carbonaceous soot and they are mixed with organic compounds.

Particles having diameter larger than 50 $\mu \mathrm{m}$ will remain in the air for several minutes and precipitate close to the pollution source. Smaller particles $\mathrm{PM}_{10}$ can remain in the air for several days and under the influence of wind they may scatter over a large area around the main source of pollution. Fine particles, size of 0.1 to $2.5 \mu \mathrm{m}$, remain in the atmosphere infinitely, whereby prevent the passage of sunlight and reduce visibility. They are usually removed from the air by rain or collision with other particles [12]

According to the origin, the suspended particles can be divided into: primary particles, emitted directly from the source of pollution (eg. construction sites, unpaved roads, chimneys, fires, etc.) and secondary particles, formed by complex mechanisms in the atmosphere after emission from pollution sources (for example, particles emitted from the power plants, industries or exhaust gases from traffic). 


\section{SOOT}

Soot is produced by burning the fossil fuels. These are fine, small particles about 5 $\mu \mathrm{m}$, that float in the air and act as a gas. They contain toxic and carcinogenic substances, easily penetrate the respiratory tract and damage them.

Soot in the suspended particles is the major threat to human health. Exposure to certain harmful substances may lead to the genetic mutations, reducing the immune capacity of the body, but most often deteriorates the existing diseases, such as asthma and chronic obstructive pulmonary disease. Some bacteria and toxic gases have the ability to get in touch with particles of soot, which further enhances their harmful impact on human health [13].

\section{ANNUAL LEVEL OF SOOT CONCENTRATION IN THE BOR MUNICIPALTY}

Table 2 shows the average annual concentrations of soot at the measuring points in the urban area of Bor in the period from 2005 to 2011. Measurements were made at the measuring points Town Park and Jugopetrol in 2005 and 2006, as well as at the measuring point Brezonik in 2008. Measurement of soot concentration is not carried out in the suburb. In the urban area, measurements are carried out at four measuring points. The largest number of measurements, during the five-year period, was carried out at the measuring point Institute, and then at the measuring points Jugopetrol, Brezonik and Town Park.

Table 2 Soot concentration at the measuring points in the municipality of Bor in the period from 2005 to 2011

\begin{tabular}{|c|c|c|c|c|c|c|c|c|c|}
\hline \multirow{2}{*}{$\begin{array}{c}\text { Measuring } \\
\text { point }\end{array}$} & \multicolumn{7}{|c|}{ Soot concentration } & \multirow{2}{*}{$\begin{array}{c}\text { Total number } \\
\text { of samples } \\
\text { (N) }\end{array}$} & \multirow{2}{*}{$\begin{array}{c}\text { Average } \\
\text { value }\end{array}$} \\
\hline & 2005 & 2006 & 2007 & 2008 & 2009 & 2010 & 2011 & & \\
\hline Brezonik & 7 & 5 & 6 & l & 19.41 & 9 & 13.8 & 949 & 10.03 \\
\hline Town Park & / & l & 4 & 7 & 10.93 & 7 & 10.2 & 883 & 7.83 \\
\hline Institute & 7 & 8 & 7 & 15 & 12 & 8.4 & 9.4 & 988 & 9.54 \\
\hline Jugopetrol & / & l & 6 & 11 & 11.05 & 5 & 6.7 & 957 & 7.95 \\
\hline
\end{tabular}

* all concentrations expressed in $\mu \mathrm{g} / \mathrm{m}^{3}$

In the urban areas, Brezonik (measuring point Brezonik) is the most polluted area, while in other areas the level of pollution is around the same and below the limit of $15 \mu \mathrm{g} / \mathrm{m}^{3}$. Total number of samples that were used in the statistical analysis is shown in Table 2.

\section{EXPERIMENTAL PART}

\section{ANALYSIS OF SAMPLES}

Measurements within the air quality control are carried out in a 24 hour continuity, seven days a month at specific measuring point, after which the mobile measuring station is moved to the other measuring point.

\section{DESCRIPTIVE STATISTICAL ANALYSIS}

Descriptive statistical analysis is a set of methods that are used for calculation, presentation and description the basic characteristics of statistical series. It includes the following actions:

1. Clustering and sorting of statistical data,

2. Presentation of statistical data and calculation, and 
3. Determining the basic measures of statistical series.

Clustering of data is done according to the values or modes of observed characteristics. As the final result of clustering, the statistical series occurs, which presents the arranged set of variations of the observed characteristics of statistical mass.

In order to find the areas with similar levels of pollution in the Bor municipality, collected data in the paper were processed using the multivariational statistical methods: regression and correlation analysis, onefactor analysis of variance (ANOVA). The data represent the soot concentrations and meteorological, processed in the statisticalcal program SPSS statistics version 17.0 $[14,15,16]$.

\section{MULTIVARIATIONAL ANALYSIS}

\section{Regression, correlation and analysis of variance}

Regression analysis is a form of multivariate analysis that describes the shape of connection between two or more variables. The simple regression model includes only two variables: one independent and one dependent. Dependent variable is the variable whose variations should be explained on the basis of movements explaining the variables. Regression model that describes the linear interdependence between two variables is called a linear regression model [17].

Correlation analysis is another form of multivariate analysis and it is used to describe the intensity, i.e. degree of agreement of variations and direction of relationships between two variables. Correlation between variables describes the significance value and the correlation coefficient that can be obtained by one-way ANOVA. Analysis of variance compares the variability of results (variance) between various groups with variability within each group.

- Indicator (quotient) F represents the variance between groups divided by the variance within the groups, the greater the value of $\mathrm{F}$ quotients, the greater the variability between groups.

- Quotient $t$ (or t-test) is the ratio of difference between two mean values of group divided with the group variability, the higher t-value, the results are more significant.

- p-value does not show the bond strength, but with how much confidence should be seen the obtained results. Significance of the analysis results is affected by the sample size. For small sample data $(\mathrm{N}=30)$, moderate correlations can be calculated. The usual level of significance is $p<0.05$.

- Correlation coefficient (R) is a degree indicator of quantitative agreement between variables and ranges from $1 \leq \mathrm{R} \leq 1$. For $\mathrm{R}=0$ there is no correlation between the variables.

- Determination coefficient $\left(R^{2}\right)$ is statistical criterion for obtaining an answer to the question of whether the chosen variable explains well the dependent variable variations in the spatial linear model. [17] The parameter $\mathrm{R}^{2}$ shows which part of variation of dependent variable is explained by regression model. It is in the range of $0 \leq R^{2} \leq 1$.

\section{EFFECT OF METEOROLOGICAL PARAMETERS ON SOOT CONCENTRATION}

Dispersion diagram is a graphical presentation the pairs of variables, which describes the nature, intensity and direction of agreement between two variables [17].

Table 3 and Figures 1, 2, 3 and 4 show the results of regression analysis at monthly level for data from automatic measuring station, installed by the Environmental Protection Agency (SEPA) at the measuring point Mining and Metallurgy Institute. Measurements were carried out in the period from early 2005 to the end of 2010 . 
Table 3 shows the results of variance analysis for soot concentrations $\left(\mu \mathrm{g} / \mathrm{m}^{3}\right)$ of temperature $\left({ }^{\circ} \mathrm{C}\right)$, humidity $(\%)$, atmospheric pressure (mbar) and wind speed $(\mathrm{m} / \mathrm{s})$ in the period from 2005 to 2010 at the measuring point Mining and Metallurgy Institute. Data from the measuring point Institute were selected for analysis because the meteorological station in the municipality of Bor is only situated at this measuring point.

Table 3 Correlation between the soot concentration and meteorological parameters in the period from 2005 to 2010 at the measuring point MMI Bor (ANOVA)

\begin{tabular}{|l|c|c|c|c|c|}
\hline Correlation & $\mathbf{R}$ & $\mathbf{R}^{\mathbf{2}}$ & $\mathbf{F}$ & $\boldsymbol{p}$-value & $\boldsymbol{t}$ \\
\hline Soot - air temperature & 0.205 & 0.042 & 2.491 & 0.120 & -1.578 \\
\hline Soot - air humidity & 0.313 & 0.098 & 6.178 & 0.016 & 2.486 \\
\hline Soot - atmospheric pressure & 0.148 & 0.022 & 1.283 & 0.262 & 1.132 \\
\hline Soot - wind speed & 0.142 & 0.020 & 1.181 & 0.282 & -1.087 \\
\hline
\end{tabular}

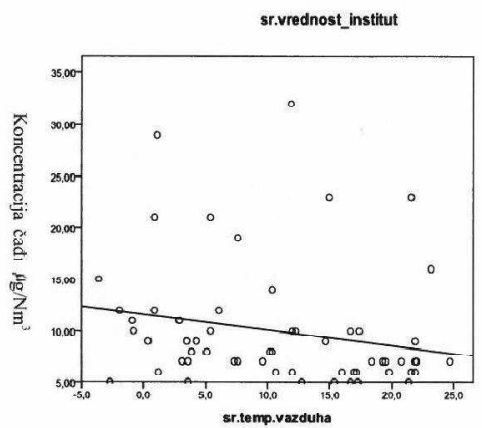

Figure 1 Correlation between the soot concentration and average air temperature from 2005 to 2010 at the measuring point MMI Bor

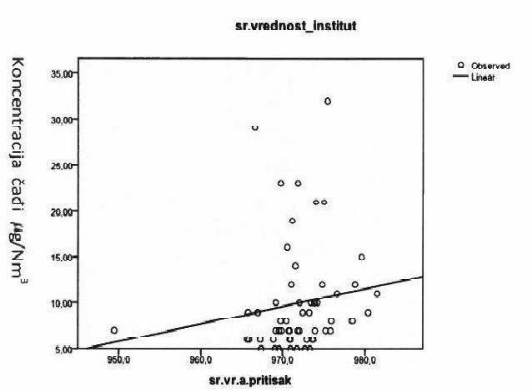

Figure 3 Correlation between the soot concentration and average value of atmospheric pressure from 2005 to 2010 at the measuring point MMI Bor

The following can be concluded based on the results of regression analysis:

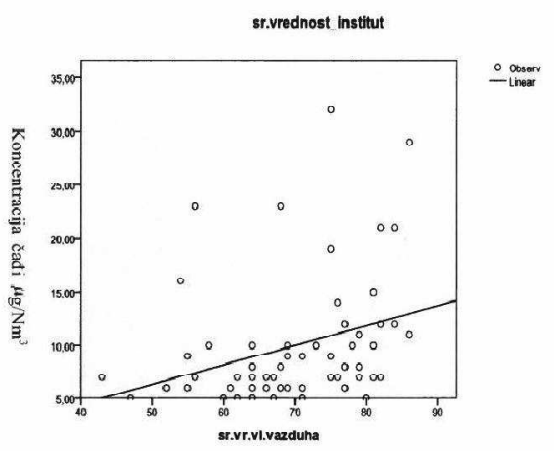

Figure 2 Correlation between the soot concentration and average air humidity from 2005 to 2010 at the measuring point MMI Bor

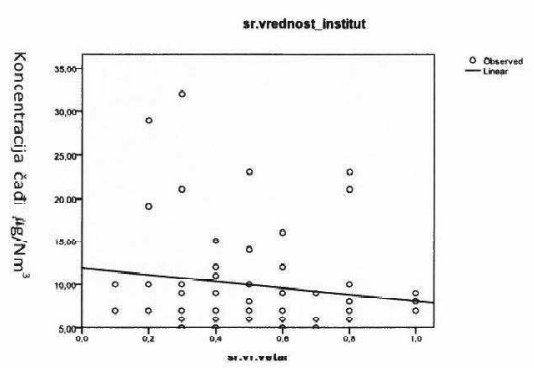

Figure 4 Correlation between the soot concentration and average value of wind speed from 2005 to 2010 at the measuring point MMI Bor

- There is a positive linear correlation of moderate strength $(\mathrm{R}=0.205)$ between 
the concentration of soot and air temperature. However, only $4.2 \%$ of variations is explained by regression analysis, which shows that in addition to temperature, there are many factors that affect the amount of soot concentration, although the level of significance is $p=0.120$. The usual level of significance is $\mathrm{p}<0.05$.

- There is a positive linear correlation of moderate strength $(\mathrm{R}=0.313)$ between the concentration of soot and air humidity. However, only $9.8 \%$ of variations is explained by regression analysis, which shows that in addition to the air humidity, there are many factors that affect the amount of soot concentration, although the level of significance is $p=0.016$. The usual level of significance is $\mathrm{p}<0.05$.

- There is a positive linear correlation of small strength $(\mathrm{R}=0.148)$ between the concentration of soot and atmospheric pressure. Only $2.2 \%$ of variations is explained by regression analysis, which shows that in addition to the atmospheric pressure there are many factors that affect the amount of soot concentration, although the level of significance is $p=0.262$. The usual level of significance is $\mathrm{p}<0.05$.
- There is a positive linear correlation of small strength $(\mathrm{R}=0.141)$ between the concentration of soot and wind speed. Only $2.0 \%$ of variations is explained by regression analysis, which shows that in addition to the wind speed there are many factors that affect the amount of soot concentration, although the level of significance is $p=0.222$. The usual level of significance is $\mathrm{p}<0.05$.

The effect of meteorological parameters: temperature $\left({ }^{\circ} \mathrm{C}\right)$, air humidity $(\%)$, atmospheric pressure (mbar) and wind speed $(\mathrm{m} / \mathrm{s})$ on the concentration of soot, showed poor correlation and poor level of significance for the results of the analysis.

\section{EFFECT OF HEATING SEASON ON SOOT CONCENTRATION}

Table 4 and Figures 5 and 6 show the results of variance analysis for soot concentrations $\left(\mu \mathrm{g} / \mathrm{m}^{3}\right)$ in the periods from October 2009 to March 2010 and in the period from April to September 2010 at the measuring point Mining and Metallurgy Institute Bor . These periods are used for analysis, because there are the most data on soot concentration for 2009 and 2010.

Table 4 Correlation between the soot concentration and heating season

\begin{tabular}{|l|c|c|c|c|c|}
\hline Correlation & $\mathbf{R}$ & $\mathbf{R}^{\mathbf{2}}$ & $\mathbf{F}$ & $\boldsymbol{p}$-value & $\boldsymbol{t}$ \\
\hline Soot - heating season & 0.038 & 0.001 & 0.258 & 0.001 & 3.48 \\
\hline Soot- season without heating & 0.117 & 0.014 & 2.505 & 0.115 & 1.583 \\
\hline
\end{tabular}

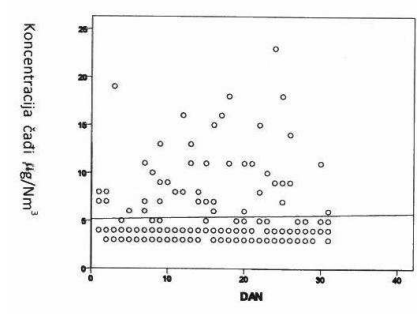

Figure 5 Simple linear correlation between the soot concentration and winter heating period from October 2009 to March 2010 at the measuring point MMI Bor

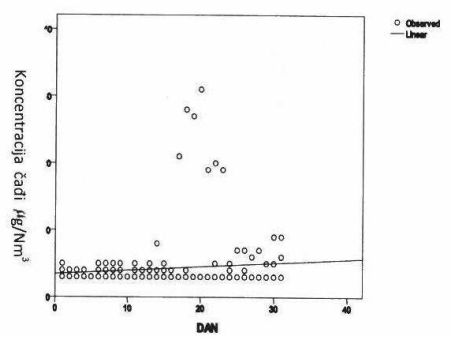

Figure 6 Simple linear correlation between the soot concentration and summer period without theating from April 2009 to September 2010 at the measuring point MMI Bor 
The following can be concluded based on the results of regression analysis:

- There is a positive linear correlation of very small strength $(\mathrm{R}=0.038)$ between the concentration of soot and heating season, i.e. the use of fossil fuels for the Heating Plant operation in Bor. Only $1 \%$ of variations is explainned by regression analysis, which shows that many other factors affect the amount of soot concentration, although the level of significance is $\mathrm{p}=0.001$. The usual level of significance is $\mathrm{p}<0.05$.

- There is a positive linear correlation of very small strength $(\mathrm{R}=0.117)$ between the concentration of soot and periods without the use of fossil fuels for heating the flats and houses. However, $14 \%$ of variations is explained by regression analysis, which shows that many other factors affect the amount of soot concentration, although the level of significance is $\mathrm{p}=0.115$. The usual level of significance is $\mathrm{p}<0.05$.

Measuring point Institute is located $1,900 \mathrm{~m}$ in direction SSW of the pollution source, and it is not in the direction of

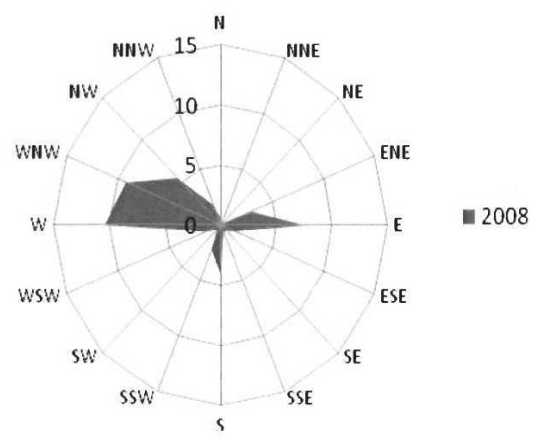

Figure 7 Wind rose (\%) for 2008 dominant winter winds, but in its vicinity there is very busy traffic line, so this explains higher correlation in the summer period than in the winter period when the number of cars is reduced.

\section{EFFECT OF WIND DIRECTION ON CONCENTRATION LEVELS OF SOOT IN THE AIR}

Analysis of the dominant wind direction is used to assess the impact of pollution sources on the level of imission of pollutants in certain areas. For this analysis, data on dominant wind direction are presented graphically in the form of polar diagrams wind roses [18], and data on pollution in the form of pollution rose $[19,20]$.

Figures 7 to 10 show the roses of soot pollution $\left(\mu \mathrm{g} / \mathrm{m}^{3}\right)$ and wind roses $(\%)$ for the observed period in the Bor municipality. Dominant wind directions were west (NW, WNW, W), eastern (ENE, E, SE), and at least was the wing from the south direction (S, SSW). Wind direction has proven to be one of the most important factors that has effect on dispersion of pollutants from the pollution sources.

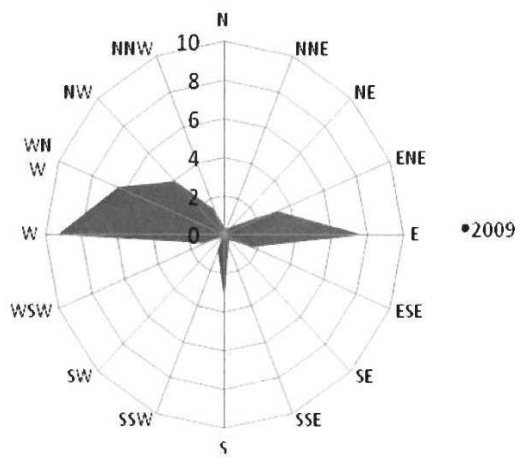

Figure 8 Wind rose (\%) for 2009 


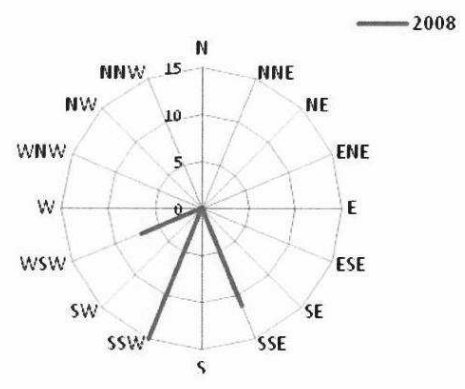

Figure 9 Rose of soot pollution $\left(\mu \mathrm{g} / \mathrm{m}^{3}\right)$ during 2008

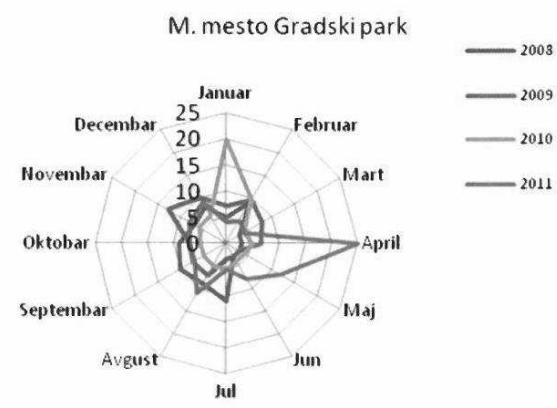

Figure 11 Soot concentration by months for 2008 and 2011 at the measuring point Town Park

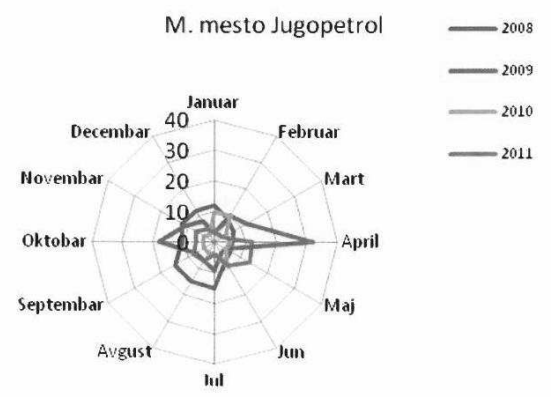

Figure 13 Soot concentration by months for 2008 and 2011 at the measuring point Jugopetrol

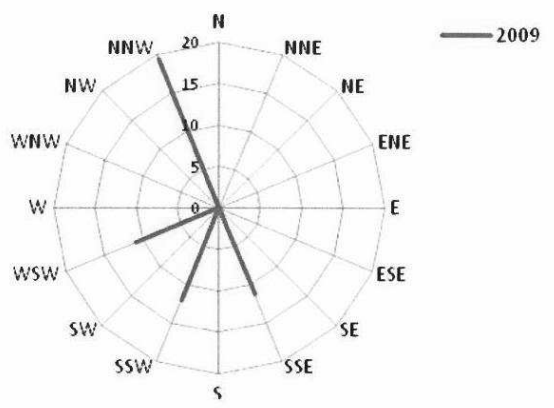

Figure 10 Rose of soot pollution $\left(\mu \mathrm{g} / \mathrm{m}^{3}\right)$ during 2009

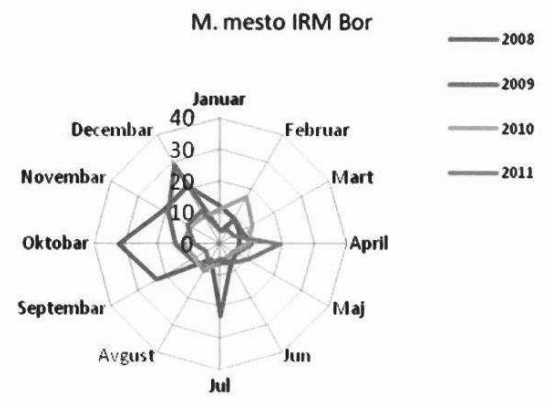

Figure 12 Soot concentration by months from 2008 to 2011 at the measuring point MMI Bor

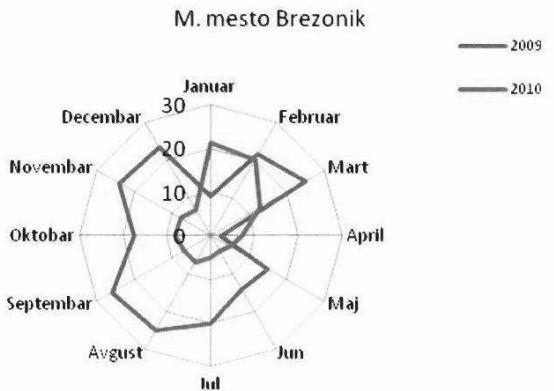

Figure 14 Soot concentration by months for 2009 and 2010 at the measuring point Brezonik 
Figures 11 and 14 shows the average monthly concentrations of soot at the measuring points in Bor in the form of polar diagrams. Based on these diagrams, it can be concluded that the soot concentrations rarely exceeded maximum allowable concentration of $15 \mu \mathrm{g} / \mathrm{m}^{3}$.

At the measuring point Institute, in the period from 2008 to 2011, the increased soot concentration above maximum allowable limit was only in 2008 from July to December. In mid July 2008, a fire broke out in the area of the airport, which is about five kilometers from Bora as well as a forest fire on Crni vrh, so that was probably the cause of increased soot concentration in this period.

In 2009, at the measuring point Brezonik, the soot concentrations were increased in February and March, as well as in the period from July to December 2009, and due to lack of other data, the other years were not analyzed. Change of meteorological conditions, change of wind directions (Figure 8 ) and a sharp drop in atmospheric pressure have caused the increased soot concentrations in the settlement Brezonik.

\section{CONCLUSION}

In order to find areas with similar levels of pollution in the Bor municipality, the collected data on soot concentration were processed by multivariate statistical methods: regression, correlation and analysis of variance.

One-factor analysis of variance and regression analysis showed that at monthly level at the measuring point Mining and Metallurgy Institute Bor:

- There is a positive linear correlation of mean strength of $\mathrm{R}=0.142$ and $\mathrm{R}=$ 0.313 between the soot concentration and meteorological parameters. However, a very small percentage of variations are explained by regression analysis of maximum $9.8 \%$, indicating that the addition of meteorological parameters, there are a lot of factors that affect the amount of soot concentrations. The significance level of $\mathrm{p}$ is in the range between 0.016 and 0.282 . The usual level of significance is $p<0.05$. Based on this, it can be concluded that there is no statistically significant correlation between soot particles and other meteorological parameters: air humidity, atmospheric pressure, wind speed and amount of precipitation.

- The effect of heating season, i.e. the use of fossil fuels for heating households on soot concentration in the air has shown that there is a positive linear correlation of a very small strength $(\mathrm{P}=0.038)$. Only $1 \%$ of variation is explained by the regression analysis, which shows that many other factors affect the amount of soot concentration, although the significance level is $p=0.001$. The usual level of significance is $\mathrm{p}<0.05$. Soot concentration depends on the direction of dominant winds.

- There is a positive linear correlation of small strength $(\mathrm{R}=0.117)$ between the soot concentration and period without use of fossil fuels for heating of flats and houses. However, 14\% of variations is explained by regression analysis, indicating that a lot of factors affect the amount of soot concentrations, significance level is $p=0.115$. The usual level of significance is $p<0.05$. In summer period, the soot concentration is increased at this measuring points due to the increased number of vehicles as well as the winds that blow in this period and which are $\mathrm{W}$ and WNW.

- Based on the obtained statistical data, it can be concluded that there is no single source of suspended soot particles, whose concentration is the most affected by humidity from meteorological parameters. Regression model has explained less than $10 \%$ of variations of soot concentrations, which means that the remaining $90 \%$ of variations were not identified. 
One-factor analysis of variance and regression analysis are given at annual level (from 2005 to 2011) at the measuring point Mining and Metallurgy Institute Bor:

- there is no statistically important correlation between the soot concentration and meteorological parameters,

- there is no statistically important correlation between the soot concentration and use of fossil fuels for heating.

Based on statistical indexes, it can be concluded that the meteorological parameters do not affect the level of soot imission in suspended particles (PM). However, small number of imission measurements could be the main reasons of a lack of correlations.

Based on the six-year average concentrations of soot at the measuring points in the urban area, it is concluded that the mean values of soot concentrations around the measuring points Brezonik, Jugopetrol, Institute and Town Park are below maximum allowable limit of $15 \mu \mathrm{g} / \mathrm{m}^{3}$ and range from 7.83 to $10.03 \mu \mathrm{g} / \mathrm{m}^{3}$. In 2009 , at the measuring point Brezonik, the mean annual average was above maximum allowable limit and it was $19.41 \mu \mathrm{g} / \mathrm{m}^{3}$, as well as at the measuring point Institute in 2008, the mean annual average was at maximum allowable limit.

However, as the number of samples from 2005 to 2009 is not the same for all measuring points and as the measurements are carried out only a week, and emission of pollutants from the Mining and Smelting Complex is almost constant with minor interruptions and oscillations in production, as well as winter when the Heating Plant is in operation, the certain measuring points may have a lower average than it is normally, while the other places occur as polluted on the basis of a small number of measurements of imissions.

In the Bor municipality, the dominant winds are of west and north-west direction (NW, WNW, W), while the winds of the east direction (ENE, E, ESE) have smaller frequency, and the winds of south direction ( $\mathrm{S}, \mathrm{SSW})$ have the smallest frequency as shown in the polar diagrams of wind rose for 2008 and 2009. Based on a polar diagram of rose of soot pollution in 2008, the highest level of pollution was recorded at the measuring point Brezonik, Institute and Jugopetrol, as well as in the settlement Metalurg and Local Community Sloga. In 2009, the highest level of contamination was recorded at the measuring points Brezonik, Institute and Jugopetrol, in the settlement Metalurg and Local Community Sloga, which are in the direction of dominant winds, or that are located in close proximity to the pollution sources. The mean annual values of soot concentrations are within normal limits. The increased soot concentration in the settlement Metalurg, Brezonik and Local Community Sloga probably comes from the use of fossil fuels for heating of houses.

\section{REFERENCES}

[1] Natural Characteristics of the Municipality of Bor, http://www.opstinabor.rs/priroda.aspx

[2] Census of Population, Households and Institutions in the Republic of Serbia, 2011; The First Results, p.65, http://media.popis2011.stat.rs/2011/prv i_rezultati.pdf

[3] Annual Report on Testing the Air Quality in Bor in 2005, Copper Institute Bor (in Serbian);

[4] Annual Report on Testing the Air Quality in Bor in 2006, Copper Institute Bor (in Serbian);

[5] Annual Report on Testing the Air Quality in Bor in 2007, MMI Bor (in Serbian);

[6] Annual Report on Testing the Air Quality in Bor in 2008, MMI Bor (in Serbian);

[7] Annual Report on Testing the Air Quality in Bor in 2009, MMI Bor (in Serbian);

[8] Annual Report on Testing the Air Quality in Bor in 2010, MMI Bor (in Serbian); 
[9] Annual Report on Testing the Air Quality in Bor in 2011, MMI Bor (in Serbian);

[10] Environmental Assessment. IPH Belgrade, 2002, Assessment of Environmental Monitoring Capacities in Bor;

[11] http://www.epa.gov/pm/, Particulate Matter (PM)

[12] http://www.ehp.qld.gov.au/gladstone/ air-quality.html Air Quality

[13] Janssen A. H., N. van Vliet P. H., Aarts F., Harssema H., Brunekreef B., Assessment of Exposure to Traffic Related Air Pollution of Children Attending Schools near Motorways, Atmospheric Environment 35(2001), pp. 3875-3884;

[14] Shridhar, V., Khillare, P. S., Agarwal, T., Ray, S., 2010. Metallic Species in Ambient Particulate Matter at Rural and Urban Location of Delhi, Journal of Hazardous Materials 175, pp. 600-607;

[15] Srivastava A., Gupta, S., Jain, V. K., 2009, Winter-time Size Distribution and Source Apportionment of Total Suspended Particulate Matter and
Associated Metals in Delhi, Atmospheric Research, 92, pp. 88-99;

[16] Griffith A. SPSS for Dummies, 2007;

[17] Mann, P.S., Introduction to Statistics; The sixth edition; Faculty of Economics, Belgrade; 2009 (in Serbian);

[18] Mukerjee, S., Shadwick, D. S., Smith, L. A., Somerville, M. C., Dean, K. E., Bowser, J. J., 2001, Techniques to Assess Cross-border Air Pollution and Application to a US-Mexico Border Region. The Science of the Total Environment, 276, pp. 205-224;

[19] Petaloti C., Triantafyllou A., Kouimtzis T., Samara C., 2006, Trace Elements in Atmospheric Particulate Matter Over a coal Burning Power Production Area of Western Macedonia, Greece, Chemosphere, 65, pp. 2233-2243;

[20] Lim J., Lee J., Moon J., Chung Y., Kim K., 2010, Source Apportionment of PM10 at a Small Industrial Area Using Positive Matrix Factorization, Atmospheric Research, 95, pp. 88100. 


\begin{tabular}{ll}
\hline \hline INSTITUT ZA RUDARSTVO I METALURGIJU BOR & ISSN: 2334-8836 \\
& UDK: 622 \\
\hline \hline
\end{tabular}

\section{UČEŠĆE ČAĐI U UKUPNOM ZAGAĐENJU VAZDUHA NA TERITORIJI OPŠTINE BOR SA STATISTIČKOM OBRADOM PODATAKA ${ }^{* *}$}

\section{Izvod}

Za efektivno upravljanje kvalitetom vazduha, jedan od glavnih uslova je identifikacija izvora zagađenja, određivanje njihovog udela u ukupnom zagađenju, kao $i$ sprovođenje mera za kontrolu $i$ redukovanje zagađenja. Cilj rada je da se na osnovu prikupljenih podataka izvede zaključak koliko čađ utiče na nivo zagađenja u Opštini Bor. Rezultati koji su prikazani u radu dobijeni su na osnovu obrađenih dnevnih $i$ srednjih godišnjih vrednosti koncentracija čađi za navedene godine. Analiza uzoraka je rađena na refraktometru u 24-časovnom kontinuitetu, 7 dana u mesecu na određenom mernom mestu. Za statističku obradu podataka korišćen je statistički softver SPSS (Statistical Package for the Social Sciences) verzija 17.0. Na osnovu rezultata koji su dobijeni primenom softvera došlo se do zaključka da postoji mala korelacije između metroloških parametara i koncentraciju čadi u opštini Bor, kao i da ne postoji povećana koncentaracije na mernim mestima uprkos pirometalurškoj preradi koncetrata bakra u RTB Bor. Veliki značaj na povećanu konctraciju čađi ima upotreba fosilnih goriva za zagrevanje domaćinstva, što u Boru nije sličaj jer se više od 90\% domaćinstva zagreva daljinskim sistemom grejanja.

Ključne reči: čađ, zagađenje, opština Bor, statistički softver SPSS

\section{UVOD}

\section{POSMATRANO PODRUČJE}

Opština Bor se nalazi u Istočnoj Srbije, prostire se na površini od $856 \mathrm{~km}^{2}$, i u njoj živi oko 50.000 stanovnika, prema popisu iz 2011. godine. $[1,2]$ Bor se nalazi na nadmorskoj visini od $378 \mathrm{~m}$, i pripada kontinentalnom klimatskom području. Prosečna godišnja količina padavina je $688 \mathrm{~mm}$, snežni pokrivač zadržava se 60 dana, a srednja godišnja temperature je $10,2{ }^{\circ} \mathrm{C}$. Područje Bora se nalazi u oblasti velike učestalosti vetrova, ali su vetrovi umerenog intenziteta. Dominantni vetrovi u posmatranom području su WNW (9,9\%), W (8,2\%) i NW (7,7\%), kao i pravca E $(7,6 \%)$, vetar iz južnog pravca manje učestalosti $(4,4 \%)$. Osnovni meterološki parametri su dati u tabeli 1. [3 - 9] Strandardna devijacija je prikazana da bi se videlo koliko elementarnih uzoraka u proseku odstupaju od aritmetičke sredine uzorka.

\footnotetext{
* Institut za rudarstvo i metalugiju Bor

** Ovaj rad je proistekao iz projekta brojTR 33038 „Usavršavanje tehnologija eksploatacije i prerade rude bakra sa monitoringom životne i radne sredine u RTB Bor Grupa", koji je finansiran sredstvima Ministarstva prosvete, nauke i tehnološkog razvoja Republike Srbije
} 
Tabela 1. Meteorološka osmatranja za period od 2005-2010. godine sa meteorološke stanice kod Instituta za rudrastvo i metalurgiju u Boru

\begin{tabular}{|c|c|c|c|c|c|c|}
\hline \multirow{2}{*}{ Meteorološki parametri } & \multicolumn{6}{|c|}{ Godina } \\
\hline & 2005. & 2006. & 2007. & 2008. & 2009. & 2010. \\
\hline \multicolumn{7}{|l|}{ Temperatura $\left({ }^{\circ} \mathrm{C}\right)$} \\
\hline Minimalna & $-2,7$ & $-3,6$ & $-0,9$ & $-1,9$ & 0,9 & $-3,0$ \\
\hline Maksimalna & 22,0 & 21,6 & 24,7 & 23,2 & 21,9 & 22,9 \\
\hline Srednja vrednost & 9,9 & 10,1 & 11,7 & 11,4 & 11,3 & 10,5 \\
\hline SD & 8,5 & 8,3 & 8,3 & 8,1 & 7,9 & 8,45 \\
\hline \multicolumn{7}{|l|}{ Vlažnost vazduha (\%) } \\
\hline Minimalna & 64 & 60 & 43 & 54 & 52 & 65 \\
\hline Maksimalna & 84 & 81 & 86 & 84 & 86 & 83 \\
\hline Srednja vrednost & 75,3 & 70,5 & 68 & 69 & 67 & 76 \\
\hline SD & 6,27 & 7,06 & 12,93 & 9,76 & 10,95 & 7,41 \\
\hline \multicolumn{7}{|l|}{ Atmosferski pritisak (mbar) } \\
\hline Minimalna & 965,7 & 965,8 & 967,4 & 949,5 & 966,6 & 964,1 \\
\hline Maksimalna & 978,5 & 981,5 & 976,7 & 980,4 & 975,1 & 972,5 \\
\hline Srednja vrednost & 971,9 & 972,7 & 971,6 & 971,1 & 971,0 & 969,4 \\
\hline SD & 3,3 & 4,6 & 2,7 & 7,6 & 3,8 & 3,46 \\
\hline \multicolumn{7}{|l|}{ Brzina vetra $(\mathrm{m} / \mathrm{s})$} \\
\hline Minimalna & 0,1 & 0,3 & 0,4 & 0,3 & 0,2 & 0,3 \\
\hline Maksimalna & 0,8 & 0,7 & 0,8 & 1,0 & 1,0 & 2,2 \\
\hline Srednja vrednost & 0,45 & 0,45 & 0,55 & 0,6 & 0,5 & 0,8 \\
\hline SD & 0,25 & 0,13 & 0,17 & 0,19 & 0,28 & 0,80 \\
\hline \multicolumn{7}{|l|}{ Maksimalni udar vetra $(\mathrm{m} / \mathrm{s})$} \\
\hline Minimalna & 4,4 & 8,2 & 11,3 & 10,3 & 7,8 & 5,3 \\
\hline Maksimalna & 17 & 17,0 & 18,4 & 19,6 & 19,4 & 16,8 \\
\hline Srednja vrednost & 12,6 & 13,6 & 14,0 & 16,5 & 13,9 & 12,2 \\
\hline SD & 3,8 & 3,1 & 2,4 & 2,8 & 3,5 & 4,73 \\
\hline
\end{tabular}

$S D$ - standardna devijacija

\section{IZVORI ZAGAĐENJA}

Primarni izvori zagađenja u Boru su rudarstvo i metalurgija. Zagađenje potiče iz procesa proizvodnje i prerade rude bakra, a izvor zagađenja su i raskrivke sa površinskog kopa i flotacijska jalovišta.

Sekundarni izvor zagađenja predstavlja čađ koja nataje sagorevanjem fosilnih goriva. Jedna količina čađi u vazduhu potiče od saobraćaja i emisija je prisutna tokom cele godine, dok je druga količina čađi je karakterističana za zimsku (grejnu) sezonu i potiče iz centralne gradske toplane, koja kao gorivo koristi ugalj.

\section{MERNA MESTA}

Raspored mernih mesta zavisi od tipa naselja, meteroloskih i topografskih faktora područja, položaja industrijskih objekata, rasporeda glavnih saobraćajnica, kao i od karaktera i količine emitovanih gasova. Monitoring kvaliteta vazduha na području 
opštine Bor obavlja se na sledećim mernim mestima:

1. Gradski park: merno mesto je udaljeno $800 \mathrm{~m} \mathrm{u}$ pravcu WSW od Rudarskotopioničkog basena Bor kao dominantnog izvora zagađenja. Nalazi se u urbanoj zoni grada (MZ Stari centar). Merno mesto smešteno je u starom delu grada u kome se nalaze glavni poslovni, trgovinski i administrativni objekti grada.

2. Institut za rudarstvo i metalurgiju Bor: merno mesto je udaljeno $1.900 \mathrm{~m} \mathrm{u}$ pravcu SSW u urbanoj zoni grada. Merno mesto nalazi se u najgušće naseljenom delu grada. U blizini mernog mesta nalazi se nekoliko škola, prometne saobraćajnice i sportsko-rekreacioni centar.

3. Jugopetrol: merno mesto je udaljeno u pravcu SSE, $2.500 \mathrm{~m}$ od izvora zagađenja. U oblast oko ovog mernog mesta živi najmanji broj stanovnika. Nalazi se u zoni predgrađa koja je ujedno i industrijska zona. Oblast je značajna po tome što se nalazi na udaru vetrova sa najvećom učestalošću.

4. Brezonik: merno mesto je udaljeno $2.000 \mathrm{~m} \mathrm{u}$ pravcu NNW u zoni predgrađa. [10]

\section{ZAGAĐENJE VAZDUHA}

Pojam zagađenja vazduha predstavlja određeni sadržaj štetnih supstanci u vazduhu. Od količine i vrste tih supstanci zavisi šteta koju mogu naneti zdravlju ljudi i životinja, kao i biljkama i materijalima. Zagađujuće materije mogu biti u čvrstom, tečnom ili gasovitom stanju. Čvrsta čestica je pojam koji se koristi za opisivanje čestica koje su suspendovane $u$ vazduhu.

Suspendovane čestice predstavljaju zagađujuće materije koje se razlikuju po veličini, masi, površini, hemijskom sastavu, mehanizmu formiranja i poreklu. Njihova koncentracija $\mathrm{u}$ vazduhu je funkcija izvora emitovanja, reakcija u atmosferi i meteoroloških uslova. Suspendovane čestice predstavljaju mešavinu veoma finih čvrstih čestica i kapi tečnosti koje se sastoje od brojnih komponenata, uključujući kiseline (nitrate i sulfate), organske materije, metale, nemetale, čađ, čestice zemlje i prašine. [11]

Prema veličini čvrste čestica mogu se podeliti na: grube čestice $(2,5-10 \mu \mathrm{m})$ koje nastaju mehanički resuspenzijom prašine, erozijom i obradom zemljišta, ili formiranjem iz industrijskih procesa, kao što su proizvodnja cementa, betona, keramike i rudarstvo. Karakteristični elementi koji se koncentrišu u ovoj frakciji su Al, Si, Ca, Fe i $\mathrm{Na}$; fine čestice $(<2,5 \mu \mathrm{m})$ koje potiču od antropogenih aktivnosti, kao što su: sagorevanje, različiti industrijski procesi, saobraćaj. Čestice prečnika $<1 \mu \mathrm{m}$ nastaju kondenzacijom metala ili organskih materija iz procesa sagorevanja; i ultrafine čestice $(0,01-0,1 \mu \mathrm{m}) \mathrm{u}$ atmosferi se nalaze $\mathrm{u}$ obliku aerosola. Ultrafine čestice najčešće potiču od sagorevanja dizel goriva, benzina i drugih organskih goriva, sastoje se od čestica ugljenične čađi i pomešane su sa organskim jedinjenjima.

Čestice koje imaju prečnik veći od $50 \mu \mathrm{m} \mathrm{u}$ vazduhu ostaju nekoliko minuta i talože se blizu izvora zagađenja. Manje čestice $\mathrm{PM}_{10}$ mogu ostati u vazduhu nekoliko dana i pod uticajem vetra mogu se rasejati na velikom području oko glavnog izvora zagađenja. Fine čestice veličine od 0,1 do $2,5 \mu \mathrm{m}$ ostaju u atmosferi beskonačno, pri čemu sprečavaju prolaz sunčeve svetlosti i smanjuju vidljivost. One se uglavnom iz vazduha uklanjaju kišom ili sudarom sa drugim česticama. [12]

Prema poreklu suspendovane čestice mogu se podeliti na: primarne čestice koje se emituju direktno iz izvora zagađenja (npr. gradilišta, neasfaltirani putevi, dimnjaci, požari, itd.) i sekundarne čestice koje nastaju složenim mehanizmima $u$ atmosferi nakon emitovanja iz izvora zagađenja (npr. čestice emitovane iz elektrana, industrije ili izduvni gasovi iz saobraćaja).

\section{ČAĐ}

Čađ nastaje sagorevanjem fosilnih goriva. To su fine, male čestice veličine oko 


\section{GODIŠNJI NIVO \\ KONCENTRACIJE ČAĐI U BORSKOJ OPŠTINI}

$5 \mu \mathrm{m}$, koje lebde u vazduhu i ponašaju se kao gas. Sadrže toksične i kancerogene materije, lako prodiru u disajne puteve i oštećuju ih.

Cađ u suspendovanim česticama predstavlja veliku opasnost po zdravlje ljudi. Izloženost pojedinim štetnim materijama može dovesti do genetskih promena, smanjenja imunološke sposobnosti organizma, a najčešće dolazi do pogoršanja postojećih bolesti, kao što su astma i hronična opstruktivna bolest pluća. Pojedine bakterije i otrovni gasovi imaju sposobnost da se povežu sa česticama čađi, što dodatno pojačava njihov štetni uticaj na zdravlje. [13]
U tabeli 2. prikazane su srednje godišnje koncentracije čađi na mernim mestima $u$ urbanoj zoni Bor u periodu od 2005. do 2011. godine. Na mernim mestima Gradski park i Jugopetrol 2005. i 2006. godine nisu vršena merenja, kao na mernom mestu Brezonik 2008. godine. U predgrađu ne vrši se merenje koncentracija čađi. U urbanoj zoni merenja se vrše na četiri merna mesta. Najveći broj merenja, u toku petogodišnjeg perioda, izvršen je na mernom mestu Institut, a zatim na mernim mestima Jugopetrol, Brezonik i Gradski park.

Tabela 2. Koncentracija čađi na mernim mestima u opštini Bor u periodu od 2005. do 2011. godine

\begin{tabular}{|l|c|c|c|c|c|c|c|c|c|}
\hline \multirow{2}{*}{$\begin{array}{l}\text { Merno } \\
\text { mesto }\end{array}$} & \multicolumn{7}{|c|}{ Koncentracija čađi } & \multirow{2}{*}{$\begin{array}{c}\text { Ukupan broj } \\
\text { uzoraka (N) }\end{array}$} & $\begin{array}{c}\text { Srednja } \\
\text { vrednost }\end{array}$ \\
\cline { 2 - 11 } & $\mathbf{2 0 0 5}$ & $\mathbf{2 0 0 6}$ & $\mathbf{2 0 0 7}$ & $\mathbf{2 0 0 8}$ & $\mathbf{2 0 0 9}$ & $\mathbf{2 0 1 0}$ & $\mathbf{2 0 1 1}$ & 949 & 10,03 \\
\hline Brezonik & 7 & 5 & 6 & $/$ & 19,41 & 9 & 13,8 & 783 & 7,83 \\
\hline $\begin{array}{l}\text { Gradski } \\
\text { park }\end{array}$ & $/$ & $/$ & 4 & 7 & 10,93 & 7 & 10,2 & 983 & 9,54 \\
\hline Institut & 7 & 8 & 7 & 15 & 12 & 8,4 & 9,4 & 988 & 7,95 \\
\hline Jugopetrol & $/$ & $/$ & 6 & 11 & 11,05 & 5 & 6,7 & 957 & \\
\hline
\end{tabular}

* sve koncentracije izražene u $\mathrm{\mu g} / \mathrm{m}^{3}$

U urbanoj sredini najzagađenjije je područje Brezonika (m. mesto Brezonik), dok je na drugim područjima nivo zagađenja približno isti $\mathrm{i}$ ispod granice od $15 \mu \mathrm{g} / \mathrm{m}^{3}$. Ukupan broj uzoraka koji su korišćeni u statističkoj analizi prikazan je u tabeli 2 .

\section{EKSPERIMENALNI DEO}

\section{ANALIZA UZORAKA}

Refrektometar je aparat koji služi za određivanje sadržaja čađi u atmosferskom vazduhu refrektometrijskom metodom. Sadržaj čađi u uzorku vazduha dobija se određivanjem refleksije crne mrlje na belom filter papiru i upoređivanjem sa inter- nacionalnom standardnom krivom. Metoda po kojoj je određivana količina čađi u vazduhu je: Određivanje indeksa crnog dima; opseg 6.2-372.1 SRPS ISO 9835:1993.

Merenja u okviru kontrole kvaliteta vazuha vrše se u 24-časovnom kontinuitetu, 7 dana u mesecu na određenom mernom mestu, nakon čega se mobilna merna stanica prenosi na drugo merno mesto.

\section{DESKRIPTIVNA STATISTIČKA ANALIZA}

Deskriptivna statistička analiza predstavlja skup metoda kojima se vrši izračunavanje, prikazivanje i opisivanje osnovnih karakteristika statističkih serija. Ona obuhvata sledeće radnje: 
1. grupisanje i sređivanje statističkih podataka,

2. prikazivanje statističkih podataka i izračunavanje, $\mathrm{i}$

3. određivanje osnovnih mera statističkih serija.

Grupisanje podataka se vrši prema vrednostima ili modalitetima posmatranih obeležja. Kao krajnji rezultat grupisanja javlja se statistička serija, koja predstavlja uređeni skup varijacija obeležja posmatrane statističke mase.

U cilju pronalaženja područja sa sličnim nivoima zagađenja u borskoj opštini prikupljeni podaci u radu su obrađeni multivarijacionim statističkim metodama: regresionom i korelacionom analizom, jednofaktorskom analizom varijanse (ANOVA). Podaci koji predstavljaju koncentracije čađi i meteorološki podaci obrađeni su u statističkom programu SPSS ststistics version 17.0 $[14,15,16]$.

\section{MULTIVARIJACIONA ANALIZA}

\section{Regresiona, korelaciona i analiza varijanse}

Regresiona analiza je vid multivarijacione analize koji opisuje oblik veze između dve ili više promenljivih. Prost regresioni model obuhvata samo dve promenljive: jednu nezavisnu i jednu zavisnu. Zavisna promenljiva je promenljiva čije varijacije treba da objasnimo na osnovu kretanja objašnjavajuće promenljive. Regresioni model opisuje linearnu međuzavisnost između dve promenljive naziva se linearni regresioni model. [17]

Korelaciona analiza je drugi vid multivarijacione analize i upotrebljava se za opisivanje jačine, tj. stepena slaganja varijacija $i$ smera veze između dve promenljive. Povezanost promenljivih opisuje p-vrednost (engl. significance value) i koeficijent korelacije, koje možemo dobiti jednofaktorskom analizom varijanse (engl. one-way ANOVA). Analiza varijanse poredi promenlji- vost rezultata (varijansu) između raznih grupa sa promenljivoću unutar svake grupe.

- Pokazatelj (količnik) F predstavlja varijansu između grupa podeljenu varijansom unutar grupa, što je veća vrednost količnika $\mathrm{F}$ to je veća promenljivost između grupa.

- Količnik t (ili t-test) predstavlja odnos razlike između dve srednje vrednosti grupe podeljenu sa varijabilitetom grupe, što je veća t-vrednost rezultati su značajniji.

- p-vrednost ne pokazuje jačinu veze, već sa koliko poverenja treba posmatrati dobijene rezultate. Na značajnost rezultata analize utiče veličina uzorka. $\mathrm{Za}$ male uzorke podataka $(\mathrm{N}=30)$, mogu se izračunati umerene korelacije. Uobičajeni nivo značajnosti je p $<0,05$.

- Koeficijent korelacije (R) je pokazatelj stepena kvantitativnog slaganja između promenljivih i kreće se u opsegu od $-1 \leq \mathrm{R} \leq 1$. Za $\mathrm{R}=0$ nema korelacije između promenjivih.

- Koeficijent determinacije $\left(\mathrm{R}^{2}\right)$ predstavlja statistički kriterijum na osnovu kojeg se dobija odgovor na pitanje da li izabrana promenljiva dobro objašnjava varijacije zavisne promenljive $u$ prostom linearnom modelu. [17] Parametar $\mathrm{R}^{2}$ pokazuje koliki je deo varijacija zavisne promenljive objašnjen regresionim modelom. Kreće se u opsegu od $0 \leq \mathrm{R}^{2} \leq 1$.

\section{UTICAJ METEOROLOŠKIH \\ PARAMETARA NA KONCENTRACIJU ČAĐI}

Dijagram rasturanja je grafički prikaz parova promenljivih koji nam govori o prirodi, jačini i smeru saganja između dve promenljive. [17]

Tabelom 3. i na slici 1, 2, 3 i 4 prikazani su rezultati regresione analize na mesečnom nivou za podatke sa automatske merne stanice postavljene od strane Agencije za 
zaštitu životne sredne (SEPA) na mernom mestu Institut za rudarstvo i metalurgiju. Merenja su sprovedena u periodu od početka 2005. do kraja 2010. godine.

$\mathrm{U}$ tabeli 3. prikazani su rezultati analize varijanse za koncentracije čađi $\left(\mu \mathrm{g} / \mathrm{m}^{3}\right)$ temperature $\left({ }^{\circ} \mathrm{C}\right)$, vlažnosti vazduha $(\%)$, atmosferskog pritiska (mbar) i brzine vetra (m/s), u periodu od 2005. do 2010. godine na mernom mestu Institut za rudarstvo i metalurgiju. Podaci sa mernog mesta Institut izabrani su za analizu, jer se meteorološka stanica u opštini Bor nalazi jedino na ovom mernom mestu.

Tabela 3. Korelacije između koncentracije čađi i meteoroloških parametara u periodu od 2005. do 2010. godine na mernom mestu IRM Bor (ANOVA)

\begin{tabular}{|l|c|c|c|c|c|}
\hline Korelacija & $\mathbf{R}$ & $\mathbf{R}^{\mathbf{2}}$ & $\mathbf{F}$ & $\boldsymbol{p}$-vrednost & $\boldsymbol{t}$ \\
\hline Čađ -Temperatura vazduha & 0.205 & 0.042 & 2.491 & 0.120 & $-1,578$ \\
\hline Čađ - Vlažnost vazduha & 0.313 & 0.098 & 6.178 & 0.016 & 2,486 \\
\hline Čađ - Atmosferski pritisak & 0.148 & 0.022 & 1.283 & 0.262 & 1,132 \\
\hline Čađ - Brzina vetra & 0.142 & 0.020 & 1.181 & 0.282 & $-1,087$ \\
\hline
\end{tabular}

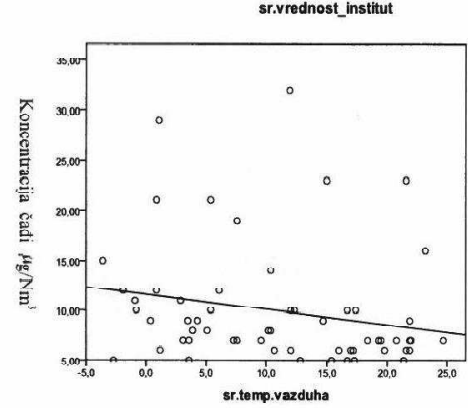

Sl. 1. Korelacije između koncentracije čađi $i$ srednje temperature vazduha od 2005. do 2010. godine na mernom mestu IRM Bor

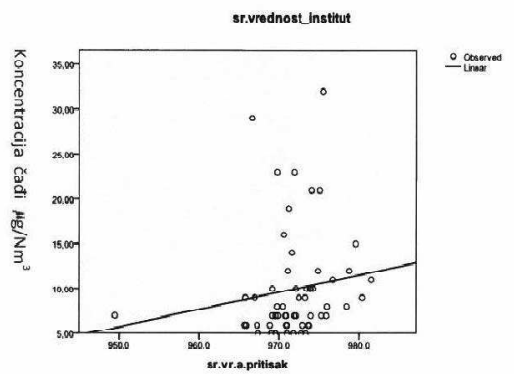

Sl. 3. Korelacije između koncentracije čađi $i$ srednje vrednosti atmosferskog pritiska od 2005. do 2010. god. na mernom mestu IRM Bor

$\mathrm{Na}$ osnovu rezultata regresione analize možemo zaključiti sledeće:

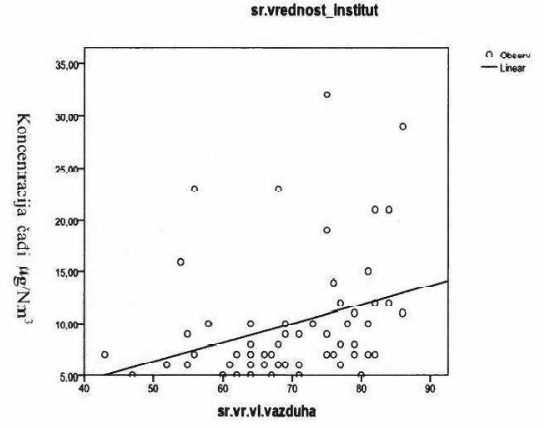

S1. 2. Korelacije između koncentracije čađi $i$ srednje vrednosti vl. vazduha od 2005. do 2010. godine na mernom mestu IRM Bor

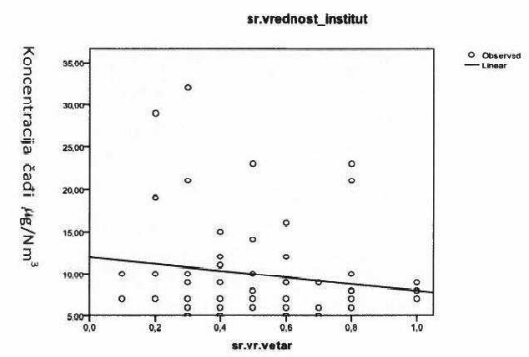

S1. 4. Korelacije između koncentracije čađi $i$ srednje vrednosti jačine vetra od 2005. do 2010. godine na mernom mestu IRM Bor

- Postoji pozitivna linearna koleracija srednje jačine $(\mathrm{R}=0,205)$ između 
koncetracije čađi i temperature vazduha. Međutim, samo 4,2\% varijacija je objašnjeno regresionom analizom, što pokazuje da pored temperature postoji još mnogo faktora koji utiču na visinu koncentracije čađi, iako je nivo značajnosti $\mathrm{p}=0,120$. Uobičajeni nivo značajnosti je $\mathrm{p}<0,05$.

- Postoji pozitivna linearna koleracija srednje jačine $(\mathrm{R}=0,313)$ između koncetracije čađi i vlažnosti vazduha. Međutim, samo 9,8\% varijacija je objašnjeno regresionom analizom, što pokazuje da pored vlažnosti vazduha postoji još mnogo faktora koji utiču na visinu koncentracije čađi, iako je nivo značajnosti $\mathrm{p}=0,016$. Uobičajeni nivo značajnosti je $\mathrm{p}<0,05$.

- Postoji pozitivna linearna koleracija male jačine $(\mathrm{R}=0,148)$ između koncentracije čađi i atmosferskog pritiska vazduha. Samo 2,2\% varijacija je objašnjeno regresionom analizom, što pokazuje da pored atmosferskog pritiska vazduha postoji još mnogo faktora koji utiču na visinu koncentracije čađi, iako je nivo značajnosti $\mathrm{p}=0,262$. Uobičajeni nivo značajnosti je $\mathrm{p}<0,05$.
- Postoji pozitivna linearna koleracija male jačine $(\mathrm{R}=0,142)$ između koncentracije čađi i brzine vetra. Ali, samo $2,0 \%$ varijacija je objašnjeno regresionom analizom, što pokazuje da pored brzine vetra postoji još mnogo faktora koji utiču na visinu koncentracije čađi, iako je nivo značajnosti $\mathrm{p}=0,282$. Uobičajeni nivo značajnosti je $\mathrm{p}<0,05$.

Uticaj meteoroloških parametara: temperature $\left({ }^{\circ} \mathrm{C}\right)$, vlažnosti vazduha $(\%)$, atmosferskog pritiska (mbar) i brzine vetra $(\mathrm{m} / \mathrm{s})$ na koncentraciju čađi, pokazale su slabu korelaciju i nedovoljan nivo značajnosti za rezultate analize.

\section{UTICAJ GREJNE SEZONE NA KONCENTRACIJU ČAĐI}

U tabeli 4. i na slici 5. i 6. prikazani su rezultati analize varijanse za koncentracije čađi $\left(\mu \mathrm{g} / \mathrm{m}^{3}\right)$ u periodima od oktobra 2009. do marta 2010. godine i u periodu od aprila do septembra 2010. godine na mernom mestu Institut za rudarstvo i metalurgiju Bor. Ovi periodi su korisćeni za analizu, jer za 2009. i 2010. godinu postoje najviše podataka o koncetraciju čađi.

Tabela 4. Korelacije između koncentracije čađi i grejne sezone

\begin{tabular}{|l|c|c|c|c|c|}
\hline Korelacija & $\mathbf{R}$ & $\mathbf{R}^{\mathbf{2}}$ & $\mathbf{F}$ & $\boldsymbol{p}$-vrednost & $\boldsymbol{t}$ \\
\hline Čađ-sezona grejanja & 0,038 & 0,001 & 0,258 & 0,001 & 3,48 \\
\hline Čađ-sezona bez grejanja & 0,117 & 0,014 & 2,505 & 0,115 & 1,583 \\
\hline
\end{tabular}

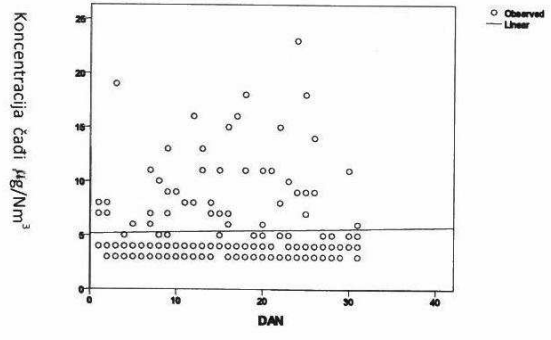

SI. 5. Prosta linearna korelacija između koncentracije čađi i zimskog perioda grejanja u periodu od oktobra 2009. do marta 2010. godine na mernom mestu IRM Bor

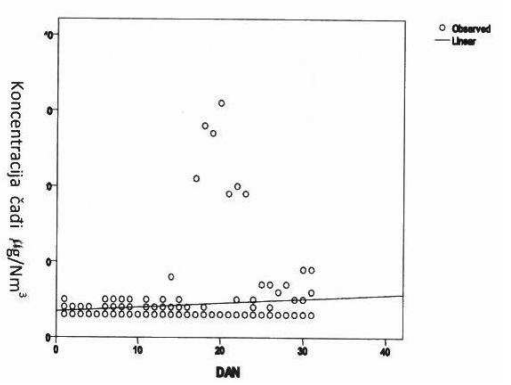

Sl. 6. Prosta linearna korelacija između koncentracije čađi i letnjeg perioda bez grejanja u periodu od aprila do septembra 2010. godine na mernom mestu IRM Bor 
$\mathrm{Na}$ osnovu rezultata regresione analize možemo zaključiti sledeće:

- Postoji pozitivna linearna koleracija veoma male jačine $(\mathrm{R}=0,038)$ između koncetracije čađi i sezone grejanja tj. upotrebe fosilnih goriva za rad Toplane u Boru. Samo 1\% varijacija je objašnjeno regresionom analizom, što pokazuje da mnogo drugih faktora utiču na visinu koncentracije čađi, iako je nivo značajnosti $p=0,001$. Uobičajeni nivo značajnosti je $\mathrm{p}<0,05$.

- Postoji pozitivna linearna koleracija male jačine $(\mathrm{R}=0,117)$ između koncentracije čađi i perioda kada se ne upotrebljavaju fosilna goriva za grejanje stanova i kuća. Međutim, 14\% varijacija je objašnjeno regresionom analizom, što pokazuje da mnogo drugih faktora koji utiču na visinu koncentracije čađi, nivo je značajnosti $p=0,115$. Uobičajeni nivo značajnosti je $\mathrm{p}<0,05$.

Merno mesto Institut je udaljeno $1.900 \mathrm{~m}$ u pravcu SSW od izvora zagađenja, i nije u pravcu dominantnih zimskih vetrova, ali u njegovoj blizini je veoma prometna saobraćajnica, tako da to objašnjava veću korelaciju u letnjem period nego u zimskom kada je broj automobila smanjen.

\section{UTICAJ PRAVCA VETRA NA NIVO KONCENTRACIJE ČAĐI U VAZDUHU}

Analiza dominantnog pravca vetra koristi se za procenu uticaja izvora zagađenja na visinu imisije zagađujućih materija $u$ određenim područjima. Za ovu analizu podaci o dominantnom pravcu vetra grafički se prikazuju u obliku polarnog dijagrama - ruže vetrova [18], a podaci o zagađenju u vidu ruže zagađenja $[19,20]$

Na slikama 7 do 10, prikazane su ruže zagađenja čađi $\left(\mu \mathrm{g} / \mathrm{m}^{3}\right)$ i ruže vetrova $(\%)$ za posmatrani period u borskoj opštini. Dominantni pravci vetrova bili su zapadnog (NW, WNW, W), istočnog (ENE, E, ESE), a u najmanje je bilo vetra iz južnog pravca (S, SSW). Pravac vetra se pokazao da je jedan od najvažnih faktora koji utiču na disperziju zagađujućih materija od izvora zagađenja.

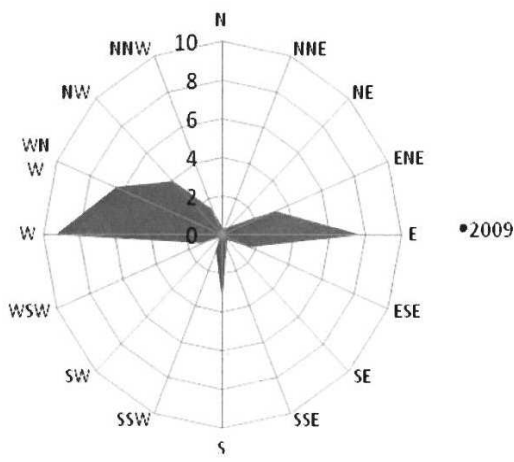

SI. 8. Ruža vetrova (\%) za 2009. god.
SI. 7. Ruža vetrova (\%) za 2008. god.

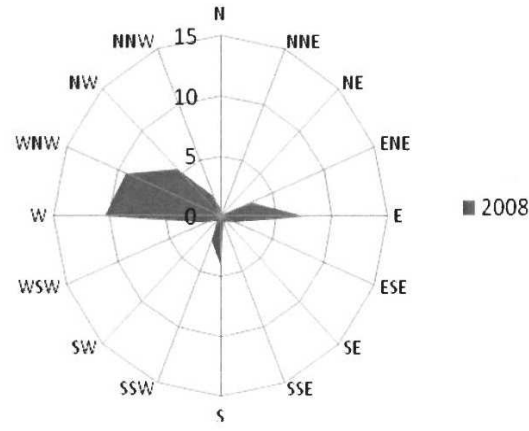




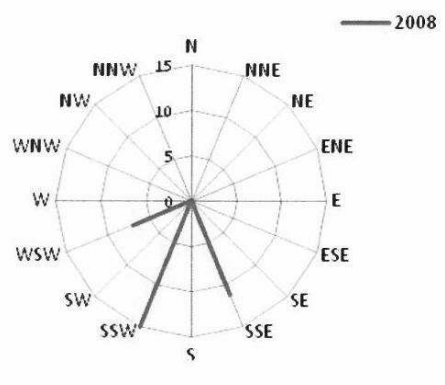

S1. 9. Ruža zagađenja čađi $\left(\mu \mathrm{g} / \mathrm{m}^{3}\right) u$ toku 2008. god.

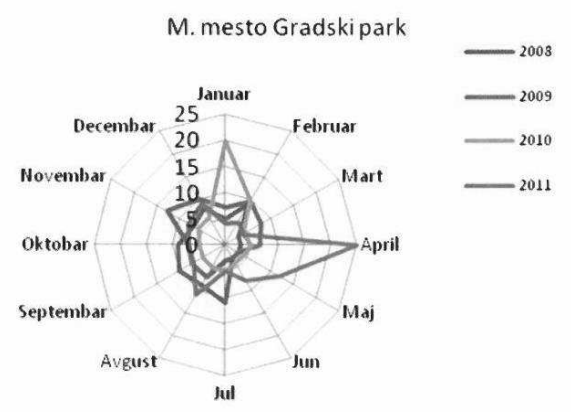

Sl. 11. Koncentracija čađi po mesecima za 2008. i 2011. godine na mernom mestu Gradski park

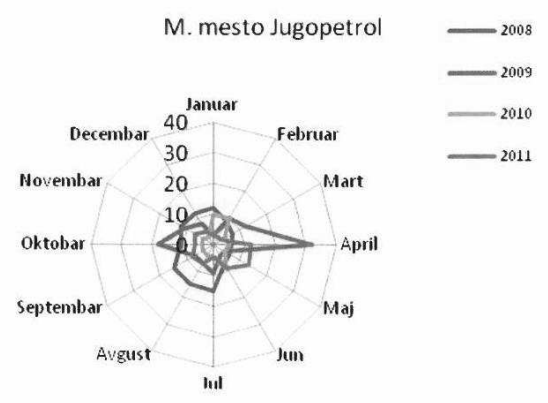

Sl. 13. Koncentracija čađi po mesecima za 2008. i 2011. godine na mernom mestu Jugopetrol

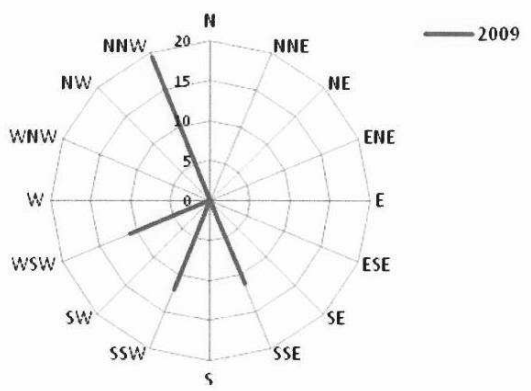

Sl. 10. Ruža zagađenja čađi $\left(\mu \mathrm{g} / \mathrm{m}^{3}\right) u$ toku 2009. god.

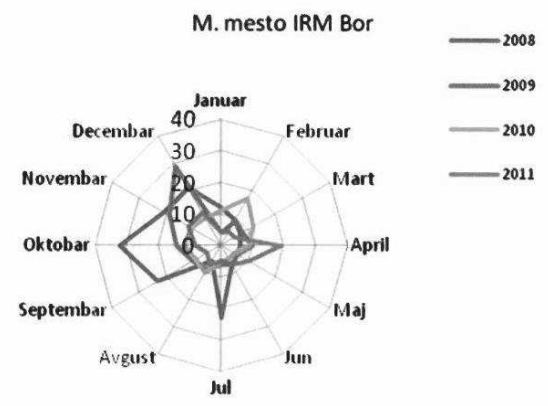

SI. 12. Koncentracija čađi po mesecima od 2008. do 2011. godine na mernom mestu IRM Bor

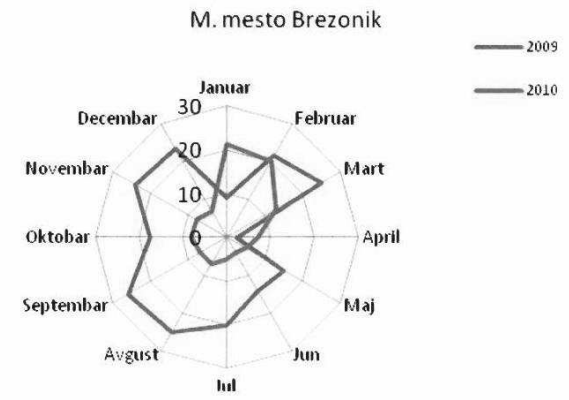

SI. 14. Koncentracija čađi po mesecima za 2009. i 2010. godine na mernom mestu Brezonik 
Na slikama 11 do 14 prikazane su srednje mesečne koncentracije čađi na mernim mestima u Boru u vidu polarnog dijagrama. Na osnovu ovih dijagrama može se zaključiti da su koncentracije čađi retko prelazile maksimalno dozvoljenu koncentra-ciju od $15 \mu \mathrm{g} / \mathrm{m}^{3}$.

$\mathrm{Na}$ mernom mestu Institut u periodu od 2008. do 2011. godine, samo u toku 2008. godine bilo je povećane koncentracije čađi iznad maksimalne dozvoljene granice, $\mathrm{i}$ to od meseca jula do decembra. Sredinom jula 2008. godine izbio je požar na području aerodroma koji je oko pet kilometara od Bora, kao i šumski požar na Crnom vrhu, pa je to verovatno uzrok povećanoj koncentraciji čađi u tom periodu.

Na mernom mestu Brezonik u 2009. godini koncenracije čađi bile su povećane $u$ februaru i martu, kao i u periodu od jula do decembra 2009. godine, zbog nedostatka podatka ostale godine nisu analizirane. Promena meteroloških uslova, promena pravca vetrova (slika 8) i nagli pad atmosferskog pritiska je prouzrokovao povećane koncentracije čađi u naselju Brezonik.

\section{ZAKLJUČAK}

U cilju pronalaženja područja sa sličnim nivoima zagađenja u borskoj opštini prikupljeni podaci o konentraciji čađi obrađeni su multivarijacionim statističkim metodama: regresiona, korelaciona i analiza varijanse.

Jednofaktorska analiza varijanse i regresiona analiza pokazali su da na mesečnom nivou na mernom mestu Institut za rudarstvo i metalurgiju Bor:

- Postoji pozitivna linearna koleracija srednje jačine od $\mathrm{R}=0,142$ do $\mathrm{R}=0,313$ između koncetracije čađi i metroloških parametara. Međutim, veoma mali procenat varijacija je objašnjeno regresionom analizom najviše 9,8\%, što pokazuje da pored metroloških parametara postoji još mnogo faktora koji utiču na visinu koncentracije čađi. Nivo značajnosti $p$ je u granicama između 0,016 i 0,282. Uobičajeni nivo značajnosti je $\mathrm{p}<0,05$. Na osnovu ovoga može se zaključiti da ne postoji statistički značajna korelacija između čestica čađi i ostalih meteoroloških prametara: vlažnosti vazduha, atmosferskog pritiska, brzine vetra i količine padavina.

- Uticaj grejne sezone tj. upotreba fosilnih goriva za grejanje domaćinstva na koncentraciju čađi u vazduhu pokazao je da postoji pozitivna linearna koleracija veoma male jačine $(\mathrm{R}=0,038)$. Samo $1 \%$ varijacija je objašnjeno regresionom analizom, što pokazuje da mnogo drugih faktora utiču na visinu koncentracije čađi, iako je nivo značajnosti $p=0,001$. Uobičajeni nivo značajnosti je $\mathrm{p}<0,05$. Koncentracija čađi zavisi od smera dominstnih vetrova.

- Postoji pozitivna linearna koleracija male jačine $(\mathrm{R}=0,117)$ između koncentracije čađi i perioda kada se ne uptrebljavaju fosilna goriva za grejanje stanova i kuća. Međutim, 14\% varijacija je objašnjeno regresionom analizom, što pokazuje da mnogo drugih faktora koji utiču na visinu koncentracije čađi, nivo je značajnosti $\mathrm{p}=0,115$. Uobičajeni nivo značajnosti je $\mathrm{p}<0,05$. U letnjem period na ovom mernom mestu je povećana koncen-tracija čađi zbog povećanog broja vozila kao i vetrova koji duvaju u tom period koji su W i WNW.

- Na osnovu dobijenih statističkih podataka, možemo zaključiti da, nepostoji jedinstveni izvor suspendovanih čestica čađi, na čiju koncentraciju od meteoroloških parametara najviše ima vlažnost vazduha. Regresionim modelom objašnjeno manje od $10 \%$ varijacija koncentracije čađi, što znači da ostalih 90\% varijacije nismo uspeli da identifikujemo.

Jednofaktorska analiza varijanse i regresiona analiza pokazali su da na godišnjem 
nivou (od 2005. do 2011. godine) na mernom mestu Institut za rudarstvo i metalurgiju Bor:

- ne postoji statistički značajna korelacija između koncentracije čađi i metroloških parametara,

- ne postoji statistički značajna korelacija između koncentracije čađi i upotrebe fosilnih goriva za zagrevanje.

$\mathrm{Na}$ osnovu statističkih pokazatelja, možemo zaključiti da meteorološki parametri ne utiču na visinu imisije čađi u suspendovanim česticama (PM). Međutim, mali broj merenja imisije tokom mogu biti glavni razlozi nepostojanja korelacija.

$\mathrm{Na}$ osnovu šestogodišnjeg proseka koncentracije čađi na mernim mestima $u$ urbanoj zoni, zaključujemo da su srednje vrednosi koncentracije čađi oko mernih mesta Brezonik, Jugopetrol, Institut i Gradski park ispod maksimalne dozvoljene granice od $15 \mu \mathrm{g} / \mathrm{m}^{3}$ i iznose od 7,83 do $10,03 \mu \mathrm{g} / \mathrm{m}^{3}$. Na mernom mestu Brezonik u 2009. godini srednji godišnji prosek bio iznad maksimalno dozvoljene granice $\mathrm{i}$ iznosio je $19,41 \mu \mathrm{g} / \mathrm{m}^{3}$, kao i na mernom mestu Institut u 2008. godini srednji godišnji prosek je bio na maksimalno dozvoljenoj granici.

Međutim, kako broj uzoraka od 2005. do 2009. godine nije isti za sva merna mesta i kako se merenja obavljaju samo nedeljno, a emitovanje zagađujućih materija iz Rudarsko-topioničarskog kompleksa je skoro konstantno sa manjim prekidima i oscilacijama $\mathrm{u}$ proizvodnji, kao i $\mathrm{u}$ zimskom periodu kada je u radu Toplana određena merna mesta možda imaju niži prosek nego što inače jeste, dok se druga mesta javljaju kao zagađena na osnovu manjeg broja merenja imisije.

U Borskoj opštini dominantni su vetrovi zapadnog i severozapadnog pravca (NW, WNW, W), dok manju učestalost beleže vetrovi istočnog pravca (ENE, E, ESE), a u najmanju učestalost imaju vetrovi južnog pravca (S, SSW) što je prikazano na polarnim dijagramima ruže vetrova za 2008 . i 2009. godinu. $\mathrm{Na}$ osnovu polarnog dijagrama ruže zagađenja čađi u 2008. godini možemo da zaključimo da najviši nivo zagađenja postoji na mernim mestima Institut i Jugopetrol, kao i u MZ Sloga i naselje Metalurg. U 2009. godini najviši nivo zagađenja je zabeležen na mernom mestu Brezonik, na mernim mestima Institut i Jugopetrol, u naselju Metalurg i MZ Sloga koja su u pravcu dominantnih vetrova ili koja se nalaze u neposrednoj blizini izvora zagađenja srednje godišnje vrednosti koncentracije čađi su u granicama normalnih vrednosti. U naselju Metalurg, Brezonik i MZ Sloga povećana koncentracija čađi verovatno potiče $\mathrm{i}$ od upotrebe fosilnih goriva za zagrevanje domova.

\section{LITERATURA}

[1] Prirodne karakteristike opštine Bor, http://www.opstinabor.rs/priroda.aspx

[2] Popis stanovništva, domaćinstva i ustanova u Republici Srbiji 2011; Prvi rezultati, str. 65 ,

http://media.popis2011.stat.rs/2011/prv i_rezultati.pdf

[3] Godišnji izveštaj o ispitivanju kvaliteta vazduha u Boru za 2005. godinu, Institut za bakar Bor

[4] Godišnji izveštaj o ispitivanju kvaliteta vazduha u Boru za 2006. godinu, Institut za bakar Bor

[5] Godišnji izveštaj o ispitivanju kvaliteta vazduha u Boru za 2007. godinu, IRM Bor

[6] Godišnji izveštaj o ispitivanju kvaliteta vazduha u Boru za 2008. godinu, IRM Bor

[7] Godišnji izveštaj o ispitivanju kvaliteta vazduha u Boru za 2009. godinu, IRM Bor

[8] Godišnji izveštaj o ispitivanju kvaliteta vazduha u Boru za 2010. godinu, IRM Bor 
[9] Godišnji izveštaj o ispitivanju kvaliteta vazduha u Boru za 2011. godinu, IRM Bor

[10] Environmental Assessment. IPH Belgrade, 2002., Assessment of Environmental Monitoring Capacities in Bor

[11] http://www.epa.gov/pm/,Particulate Matter (PM)

[12] http://www.ehp.qld.gov.au/gladstone/ air-quality.html, Air quality

[13] Janssen A. H., N. van Vliet P. H., Aarts F., Harssema H., Brunekreef B., Assessment of Exposure to Traffic Relatedair Pollution of Children Attending Schools Near Motorways, Atmospheric Environment 35(2001), p. 3875-3884

[14] Shridhar, V., Khillare, P. S., Agarwal, T., Ray, S., 2010. Metallic species in ambient particulate matter at rural and urban location of Delhi. Journal of Hazardous Materials 175, p. 600-607.

[15] Srivastava A., Gupta, S., Jain, V. K., 2009, Winter-time size distribution and source apportionment of total suspen- ded particulate matter and associated metals in Delhi. Atmospheric Research, 92, p. 88-99

[16] Griffith A. SPSS for Dummies, 2007.

[17] Mann, P.S., Uvod u statistiku; Šesto izdanje; Ekonomski fakultet Beograd; 2009.

[18] Mukerjee, S., Shadwick, D. S., Smith, L. A., Somerville, M. C., Dean, K. E., Bowser, J.J., 2001, Techniques to assess cross-border air pollution and application to a US-Mexico border region. The Science of the Total Environment, 276, p. 205-224.

[19] Petaloti C., Triantafyllou A., Kouimtzis T., Samara C., 2006, Trace Elements in Atmospheric Particulate Matter Over a coal Burning Power Production area of Western Macedonia, Greece. Chemosphere, 65, p. 2233-2243.

[20] Lim J., Lee J., Moon J., Chung Y., Kim K., 2010, Source Apportionment of PM10 at a Small Industrial area using Positive Matrix Factorization. Atmospheric Research, 95, p. 88-100. 